Jurnal Keperawatan Padjadjaran

ISSN 2338-5324 (print)

ISSN 2442-7276 (online)

Online di http://jkp.fkep.unpad.ac.id

DOI : $10.24198 / \mathrm{jkp}$

\title{
Factors that Correlate with The Health Services Seeking on Breast Cancer Patients
}

\author{
Dini Fathania, Laili Rahayuwati, Desy Indra Yani \\ Faculty of Nursing, Universitas Padjadjaran, Bandung, Indonesia \\ Corresponding Email: dini_fathania@yahoo.com
}

Submitted: 10-07-2018 Accepted: 10-04-2019 Published: 28-04-2019

\begin{abstract}
Most cases of breast cancer are found to be in an advanced stage. This is because of the patient delay in coming to health service after the emergence of early symptoms of breast cancer. It is necessary to identify factors that allegedly prevent patients from seeking health services as early as possible. The purpose of this study was to analyze factors related to the search for health services. This research used cross-sectional method. The population of this study was breast cancer patients where the sampling technique using consecutive sampling with the number of samples researched as many as 100 people. Data were obtained through a reliable questionnaire to use (Alpha Cronbach's questionnaire $=0.92$, Alpha Cronbach's health questionnaire $=0.85$ ). Analysis of this research data using univariate (frequency distribution), bivariate (Chi-Square) and multivariate (logistic regression). The result of bivariate analysis showed that the variables related to health seeking behavior are education ( $\rho$ value $=0.02 ; r=0.3$ ) and health belief ( $\rho$ value $=0.01 ; r=0.24)$. While the variables that most related to health service seeking behavior was health belief ( $\rho$ value $=0.02$ ) and OR value 3.46. This could be caused by patient's health belief in which the patient assumes that the symptoms were not dangerous and the choice of alternative medicine as the first choice and the patient's fear of treatment due to lack of information that obtained by the patient. It can be concluded that health beliefs are the most correlated factor with health-seeking behavior so it is necessary to consider the prevention efforts of breast cancer especially related to health belief. Community beliefs about routine health checks should be key interventions such as counseling and discussions with the community regarding the importance of routine health screening as part of early detection of disease.
\end{abstract}

Keywords: Breast Cancer, factors, health beliefs, health seeking behavior. 
Dini Fathania: Factors that Corelate with The Health Services Seeking on Breast Cancer Patients

\section{Introduction}

Breast cancer is one of the health problems that cause a high number of morbidity and death in women. This is reinforced by data shown by Yang Liu, Jian Zhang, Rong Huang, We-Liang Feng, Ya-Nan Kong et al. (2017), where it is estimated that about $15 \%$ of deaths in women in the world are caused by breast cancer. Not only in the world level, Indonesia also has a high incidence of breast cancer (Yang Liu et al., 2017).

Based on the data from Infodatin Kemenkes RI(2015), breast cancer, especially in Indonesia is cancer with the highest percentage of new cases that reached $43.3 \%$ with the percentage of death reached $12.9 \%$. Based on the data obtained from Bandung Health Department, the incidence of breast cancer in the city of Bandung is still high. The number of breast cancer patients from year 2014 to 2015 has increased from 239 cases to 523 cases. Despite the decline in the number of breast cancer cases from 2015 to 2016, the incidence of breast cancer cases is still high in 459 cases (Infodatin Kemenkes RI, 2015, Bandung Health Department, 2016).

The earlier treatment of breast cancer might be beneficial to reduce morbidity and mortality rate. Not only is needed treatment done as soon as possible, prevention is needed to reduce the rate of breast cancer in the late stages. he results of the research conducted by Unger-Saldana et al. (2015) showed that most of the respondents in their study $(45 \%)$ were diagnosed as having advanced stage III and stage 4 . This could be caused by various factors such as the delay of the patient themself to seek treatment and delay in diagnosis of the system health services (Unger-Saldana et al., 2015)

Some actions can be done in preventing the occurrence of breast cancer such as implementing a healthy lifestyle and breast self-examination regularly, especially for women aged over 50 years. Unfortunately, prevention behavior like breast selfexamination has not become something that is needed and important to be done by women. It can be seen from a research conducted by Kusumawati and Miasari (2014) which shown that someone who does not have a family history with breast cancer, 55\% among them do not do breast self-examination as a form of early detection of breast cancer (Putri, 2015; Kusuwamati \& Miasari, 2014 ).

The high number of women who did not make early breast cancer detection efforts had an influence on the discovery of breast cancer cases diagnosed in an advanced stage (Wang,2017). Mirfarhadi et al. (2017) in his study explains that there is one predictive factor that is significantly related to the delay of diagnosis and treatment in breast cancer patients one of which is not doing breast selfexamination (SADARI) (Mirfarhadi et al., 2017).

Symptomatic patients who do not receive immediate medical help may be diagnosed with cancer in an advanced stage. Advanced stages of breast cancer will affect the quality of life and the prognosis of the patients. In stage I, the patient has a $70 \%$ chance of recovery so that the quality of life is not too disturbed. In stage II the possibility of recovery is $30-40 \%$, which causes the quality of life at this stage began to be disturbed, especially physical and psychological problems. In stage III, the likelihood of life is low so the quality of life decreases. In stage IV, therapy is not very meaningful, causing the quality of life to be very bad. This indicates that the impact of the more late a person is diagnosed with cancer will affect the poor quality of life of the person (Moatter et al., 2015).

The lower mortality rates of breast cancer compare to the morbidity rates indicates the possibility of cancer recovering if it detected and handled earlier. About 30-50\% of cases of cancer recently can be prevented (WHO, 2017). This can be achieved through behaviors that stay away from risk factors and the implementation of prevention strategies from existing research evidence. The burden of cancer can be decreased through early detection and good management to prevent further progressing of cancer that have a high chance of being cured if diagnosed early and treated adequately (WHO, 2017).

The results of a study by Wang (2017) showed a similar data which that early cancer detection will reduce the number of further pain and mortality caused by breast cancer significantly. The most important point for a good prognosis in cases of breast cancer is to identify the presence of cancer cells in the 
Dini Fathania: Factors that Corelate with The Health Services Seeking on Breast Cancer Patients

early stages. There are now many approaches or actions to diagnose breast cancer as early as possible. Unfortunately, at this time almost $80 \%$ of cases of breast cancer in Indonesia diagnosed or known by health workers when it entered the advanced stage. This can be due to one of them by the expensive diagnostic checks that need to be done, takes a long time and is considered unsuitable for young women (Wang, 2017).

The number of cases of breast cancer found in advanced stages is caused by the delay in making decisions when they should go to health services (Glenz et al., 2002). Decision making of a person to visit or utilize existing health services is influenced by several factors that are important to be known, especially by health provider. There are many health models applied in the nursing practice such as Behavioral Model of Health Service Utilization to understand the attitudes and values of clients on health and disease, and to provide effective health services (Glenz et al., 2002; Notoatmodjo, 2012).

Theoretical approach of the Behavioral Model of Health Service Utilization allows to assist health professionals, especially nurses, where the use of this theory allows for an illustration of the relationships between the determinant factors of the use of health services, alleviating the forecasting of future needs on health services, determine the presence or absence of services from the use of health services that are one-sided, suggest ways of manipulating policies related to variables in order to provide better health services especially for breast cancer patients (Glenz et al., 2002; Notoatmodjo, 2012). This theory explains that there are three main factors that influence health service utilization behavior including predisposing, enabling, and need factor. Predisposing factors are factors inherent in the individual itself (such as age, sex, marital status, race, education, family type, occupation, health knowledge and beliefs). The enabling factors explain the individual's capabilities and the means by which the individual may utilize health care facilities (such as family income, health insurance ownership, access to health services and available health services). As for the need factor is a factor where a new person utilizes health services when individuals feel disturbed by his health condition (Glenz et al., 2002; Notoatmodjo, 2012).

Health workers, especially nurses, need to analyze the process from the beginning of the onset of symptoms until the patients get treatment for breast cancer so the nurses know the factors that affect the patient's delay in obtaining medical help. There are two main factors that affect the delay of breast cancer patients to come to the health service including internal factors derived from within the individual itself and external factors originating from outside the breast cancer patients (eg. family) and health organizations that can facilitate early detection of cancer (Brousselle et al., 2017).

Factors included in the internal factors include the knowledge factor of the patient where the average patient does not know that a lump that appears is something that must be checked immediately so that when the symptoms appear most of patients do not take care it seriously. In addition, the presence of excessive fear and anxiety also became one of the obstacles of breast cancer patients to immediately check the situation when first appeared symptoms such as a lump in the breast (Anggraeni, Ngatimin, \& Arsin, 2012). While that includes into external factors such as inequity access to the diagnosis that affects the early detection of cancer and family factors that also have an important role in decision making patients to come to health services. Families are the main drivers for their self-examination but breast cancer patients tend to ignore the invitations of their families. The suggestion from the study says that there needs to be a deeper involvement of health workers, especially in the field of better health promotion so that knowledge does not cause anxiety or excessive acknowledgment in patients (Brousselle et al., 2017, Anggraeni et al., 2012) .

In contrast to previous research results, Hikmanti et al. (2007) in his study said that there is no significant relationship of knowledge, work, fear, family support, health insurance, medical treatment costs, medical treatment other than hospital, family history and education of respondents to delayed treatment of breast cancer. This is made possible by other factors such as factors from local community leaders or factors of 
Dini Fathania: Factors that Corelate with The Health Services Seeking on Breast Cancer Patients

health workers who have an influence on the immediate medical search behavior of breast cancer patients (Hikmanti et al., 2007).

West Java is the third highest province for most cases of breast cancer in Indonesia after Central Java and East Java. Therefore, it needs special attention by health workers, especially regarding the delay in breast cancer patients to be diagnosed in the early stages so as to facilitate treatment and increase the likelihood of recovery. According Pahria (2017) West Java is the province with the largest population in Indonesia where approximately $49.3 \%$ of its citizens are female. About $0.5 \%$ of women in West Java have breast cancer and predicted about $9.6 \%$ of young women in West Java are at risk of developing breast cancer. This needs to be an important concern for nurses in order not to increase the incidence rate of breast cancer in West Java (Pahria, 2017).

Nurses can play an active role in decreasing the incidence of late diagnosis in breast cancer patients. Nurses can play an active role in preventing late diagnosis in breast cancer patients especially in the prevention phase that focuses on groups at risk of developing breast cancer. Nurses can screen women who have a history of breast cancer and behaviors that are at risk for breast cancer (eg. smoking) where the nurse reviews risk group knowledge about signs and symptoms that need to be alerted towards breast cancer and invites the risk group to routinely perform breast selfexamination behavior (check breast itself) and within a certain timeframe perform a radiological examination that can detect early breast cancer (Melo et al., 2017).

Based on some data from the results of research conducted by Brousselle (2017), Wang (2017), and Hikmanti (2007) where there are still some differences related factors that affect the decision making of breast cancer patients (especially factors knowledge, fear and support family) to visit health care facilities as early as possible and in West Java itself is not known for sure the underlying factors of decision making treatment of cancer patients, especially for patients in the city of Bandung.

Researchers are interested to know what factors and what the main factors behind a person late diagnosed breast cancer, especially in the area of West Java. Through this research is expected to get a picture of the constraints of patients come to health services when the initial symptoms of breast cancer appear. By knowing it is expected to be done in the future secondary preventive efforts where health workers try to prevent cancer develop and cause complications or cause severity that will affect the quality of life of patients with breast cancer that will also affect the possibility of patients getting closer to the death as well it is expected that in the future patients who have symptoms of breast cancer in the early stages can be known as soon as possible so that healing efforts can be done more leverage.

This study aims to examine factors related to the search for health services in breast cancer patients with the specific aim of analyzing the relationship between predisposing factors: age, marital status, history of breast cancer, education, occupation, health knowledge and beliefs with health seeking behavior behavior as soon as possible in breast cancer patients; analyze the relationship between supporting factors: income, access to health services and ownership of health insurance with health seeking behavior as soon as possible in breast cancer patients; and analyze the factors most closely related to the search for health services as soon as possible by breast cancer patients.

\section{Method}

This study a cross-sectional study design with a total sample of 100 breast cancer patients that obtained from the cross sectional study sample calculation formula. The location of this study was in the working area of Bandung City Health Office and Cancer Stop Home in Sukajadi District. The data had collected from March to June 2018. Data collection techniques were conducted by distributing questionnaires to respondents to find out factors related to health service search behavior in breast cancer patients.

\section{Data Analysis}

Univariate analysis was done to describe the frequency distribution of several variables by calculating the median value of the total score of the respondents of each 
Dini Fathania: Factors that Corelate with The Health Services Seeking on Breast Cancer Patients

variable. Bivariate analysis was done to see the relationship between two variables (independent and dependent variables) using Chi-Square test. Multivariate analysis was done using logistic regression test. The data

was analyzed using a statistical software.

\section{Result}

Predisposing Factors with Health Service Table 1 Cross-Tabulation Between Predisposing Factors and Health-Seeking Behavior $(\mathbf{N}=100)$

\begin{tabular}{|c|c|c|c|c|c|c|}
\hline \multirow{3}{*}{ Variables } & \multicolumn{4}{|c|}{ Health service seeking behavior } & \multirow{3}{*}{$\rho$ value } & \multirow{3}{*}{$\mathbf{X}^{2}$} \\
\hline & \multicolumn{2}{|c|}{$\geq 3$ months } & \multicolumn{2}{|c|}{$<3$ months } & & \\
\hline & (f) & $(\%)$ & (f) & $(\%)$ & & \\
\hline \multicolumn{7}{|l|}{ Age } \\
\hline$>40$ years & 60 & 60.00 & 22 & 22.00 & 0.30 & 1.04 \\
\hline$\leq 40$ years & 11 & 11.00 & 7 & 7.00 & & \\
\hline \multicolumn{7}{|l|}{ Marital status } \\
\hline Married & 70 & 70.00 & 29 & 29.00 & 1.00 & 0.00 \\
\hline Single & 1 & 1.00 & 0 & 0.00 & & \\
\hline \multicolumn{7}{|l|}{ Education } \\
\hline$\leq$ High school & 69 & 69.00 & 24 & 24.00 & $0.02^{*}$ & 4.55 \\
\hline$>$ High school & 2 & 2.00 & 5 & 5.00 & & \\
\hline \multicolumn{7}{|l|}{ Occupation } \\
\hline Working & 26 & 26.00 & 16 & 16.00 & 0.08 & 2.90 \\
\hline Not working & 45 & 45.00 & 13 & 13.00 & & \\
\hline \multicolumn{7}{|l|}{$\begin{array}{l}\text { Family } \\
\text { history }\end{array}$} \\
\hline No & 70 & 70.00 & 26 & 26.00 & 0.07 & 2.27 \\
\hline Yes & 1 & 1.00 & 3 & 3.00 & & \\
\hline \multicolumn{7}{|l|}{ Knowledge } \\
\hline $\begin{array}{l}\text { Less } \\
\text { knowledge }\end{array}$ & 28 & 28.00 & 11 & 11.00 & 0.89 & 0.02 \\
\hline $\begin{array}{l}\text { Good } \\
\text { knowledge }\end{array}$ & 43 & 43.00 & 18 & 18.00 & & \\
\hline \multicolumn{7}{|l|}{ Health belief } \\
\hline Negative & 39 & 39.00 & 8 & 8.00 & $0.01^{*}$ & 6.18 \\
\hline Positive & 32 & 32.00 & 21 & 21.00 & & \\
\hline
\end{tabular}

Table 2 Cross Tabulation Between Enabling Factors and Search Behavior Health Services $(\mathrm{N}=\mathbf{1 0 0})$

\begin{tabular}{|c|c|c|c|c|c|c|}
\hline \multirow{3}{*}{ Variables } & \multicolumn{4}{|c|}{ Health service seeking behavior } & \multirow{3}{*}{$\rho$ value } & \multirow{3}{*}{$\mathbf{X}^{2}$} \\
\hline & \multicolumn{2}{|c|}{$\geq 3$ months } & \multicolumn{2}{|c|}{$<3$ months } & & \\
\hline & (f) & $(\%)$ & (f) & $(\%)$ & & \\
\hline \multicolumn{7}{|l|}{ Income } \\
\hline$<$ Regional Minimum Wage & 66 & 66.00 & 23 & 23.00 & 0.07 & 2.64 \\
\hline$\geq$ Regional Minimum Wage & 5 & 5.00 & 6 & 6.00 & & \\
\hline \multicolumn{7}{|l|}{ Health insurance } \\
\hline No & 1 & 1.00 & 0 & 0.00 & 1.00 & 0.00 \\
\hline Yes & 70 & 70.00 & 29 & 29.00 & & \\
\hline
\end{tabular}


Dini Fathania: Factors that Corelate with The Health Services Seeking on Breast Cancer Patients

\begin{tabular}{|lcccccc|}
\hline Access to health service & & & & & & 0.49 \\
Unaffordable & 14 & 14.00 & 4 & 4.00 & 0.48 & 0.00 \\
Affordable & 57 & 57.00 & 25 & 25.00 & & \\
\hline
\end{tabular}

Table 3 Multivariat Analysis of Health Service Seeking Behavior

\begin{tabular}{lccc}
\hline \multicolumn{1}{c}{ Variable } & Coefficient & P & OR (CI 95\%) \\
\hline Education & 1.27 & 0.19 & $3.56(0.53-23.81)$ \\
Occupation & -0.60 & 0.23 & $1.83(0.20-1.48)$ \\
Family history & -1.82 & 0.17 & $0.16(0.01-2.22)$ \\
Health belief & 1.24 & 0.02 & $3.46(1.24-9.62)$ \\
Income & 0.57 & 0.44 & $1.77(0.41-7.65)$ \\
Constant & -0.33 & 0.06 & 0.72 \\
\hline
\end{tabular}

\section{Search Behavior}

Table 1 above showed some variables that influence the delay in the seeking for health services ( $\geq 3$ months). The delay in the seeking for health services is mostly found in respondents aged $>40$ years $(60.00 \%)$. Among marital marriage status, those status with married status $(70.00 \%)$ showed a higher percentage on health service seeking behavior. Among occupation group, respondents who were not working showed a higher percentage on health service seeking behavior $(45.00 \%)$. Among family history group, respondents that had no history of breast cancer in the family showed a higher percentage on health service seeking behavior (70.00\%). Among knowledge group, respondents that had a good knowledge of breast cancer showed a higher percentage on health service seeking behavior $(43.00 \%)$, and had negative health confidence showed higher percentage on health service seeking behavior $(39.00 \%)$. While the results of Chi Square test showed that predisposing factors that have relationship with health service search behavior is the variable of education and health belief. While the variable age, marital status, occupation, history of breast cancer and knowledge there is no relationship with health seeking behavior in breast cancer patients

\section{Enabling Factors with Health Service Search Behavior}

From table 2 above shows that the delay in the search for health services ( $\geq 3$ months) mostly occurred in respondents with income
$<$ regional minimum wage $(66.00 \%)$, health insurance $(70.00 \%)$ and access to affordable health services $(57.00 \%)$. While the results of Chi Square test show that of the three supporting factors of income, ownership of Askes and Askes to health services all three have no relationship with health service search behavior.

\section{Variable that have significant correlation with health service seeking}

Of the five influential variables, health confidence was the only variable that significantly correlated with the health service seeking with the odd-ratio of 3.46. This means that breast cancer patients who have positive health beliefs will conduct health service search as soon as possible 3 times higher than patients who have negative health belief, after controlled variable education, occupation, income and history of breast cancer in the family.

\section{Discussion}

\section{Predisposing Factors with Health Service Search Behavior}

Based on education, respondents who experienced the most delay in the search for health services were respondents with low education level ( $\leq$ high school). In this study, there was a relationship between education and health seeking behavior in breast cancer patients. This means that the higher the level of a person's education, the higher possibility not to be late in searching for health services. Yang Liu et al. (2017) in his research that 
Dini Fathania: Factors that Corelate with The Health Services Seeking on Breast Cancer Patients

women who have lower levels of education were likely to have poorer quality of life. People with low education usually live in areas far from urban and technological advancements in which one is difficult to be exposed to the possibility of early breast cancer screening so that the risk of delay in the search for health services and the diagnosis of breast cancer is higher in women with lower levels of education.

Based on the health beliefs, respondents experiencing delays in the search for health services were those who have negative health beliefs $(39.00 \%)$. In this study, there was a relationship between health beliefs and delay in the search for health services. This may be due to several factors such as the patient presuming that the symptoms were not dangerous, the selection of traditional medicine as the first treatment, and the fear of breast cancer examination and treatment (Brousselle et al., 2017). Symptoms that appear were often regarded as something that was not dangerous because in general, the initial symptoms were felt like a lump does not cause pain so that they regarded it as something that was not harmful. Selection of treatment were the most of the respondents said they had undergone traditional treatment first before finally choosing medical treatment. As Rahayuwati's et al. study (2016) stated that the selection of therapies for breast cancer patients was influenced by the families and the environment. This was a lot happening in the community where people were more confident in what was widely spread in the community through word of mouth including traditional medicine that grows around the community. Fear of treatment also became one of the factors that influence the respondent's belief in health. Like chemotherapy treatment, many patients got information from the neighborhood around the dwelling that chemotherapy was a terrible treatment when it is well prepared then the side effects can be minimized.

\section{Enabling Factors with Health Service Search Behavior}

Based on the income, respondents who experienced the most delay were respondents with income $<$ regional minimum wage $(66.00 \%)$. In this study there is no relationship between income and health seeking behavior in breast cancer patients. This means both women who have enough or insufficient income allow for late in searching for health services after the initial symptoms of breast cancer appear. Women who have enough income allow higher rates for early detection of breast cancer. But the economic status of a good economy is usually associated with a good job that allows to have a busy enough and not too concerned with health problems themselves. Women who have less income are more likely to be late in searching for health services because they do not have the cost to come to health services (Arndt et al., 2002).

Based on the ownership of the health insurance, respondents who experienced the most delay in the search for health services were the respondents who had health insurance $(70.00 \%)$. In this study there is no relationship between the ownership of the health insurance and the delay in conducting health service search. This can be interpreted that people who have health insurance is not necessarily searching for health services as soon as possible. Rossalia and Wibawa (2016) in his research mentioned that patients who do not have Askes tend to be late in searching for health services because of the limitations in terms of the cost of treatment for breast cancer costs considerable. While in this study, most of the respondents who experienced delays precisely the patients who have health insurance. This is because the fear of treatment is greater, they tend to choose an alternative treatment that usually the side effects of treatment is very minimal. Most respondents also feel that the symptoms of the illness are not so dangerous that when the respondent feels no pain, the health costs borne by the government will not guarantee the patient to come to the health service as soon as possible.

Based on access to health services, respondents who experienced the most delay in the search for health services were those who said access to health services was still affordable $(57.00 \%)$. In this study there is no relationship between access to health services and health service search behavior. This can mean that the patient whose residence is close to the health service is not necessarily go to 
Dini Fathania: Factors that Corelate with The Health Services Seeking on Breast Cancer Patients

health services as soon as possible. Brousselle et al. (2017) in his research stated that so far the closest health facilities to the community residence usually have poor infrastructure facilities and less complete so that patients need time to come to health services that can diagnose diseases such as breast cancer.

\section{Variable that have significant correlation with health service seeking}

Health confidence is the most influential variable among other variables because in this health belief includes several factors that affect the behavior of a person such as the perception of the disease and the fear of an examination. So when a person feels that he is healthy when in fact there is a health problem and not immediately done the examination then this is the cause of a late person in searching for health services. The results of this study also indicate that breast cancer patients who have negative health beliefs will not conduct health service search as soon as possible 3.46 times higher than patients who have positive health beliefs.

The role of health workers is considered very important because when the patient considers the initial symptoms that appear is not a dangerous thing is required suatau prevention efforts to the wider community so that people assume that the symptoms that appear is not a thing that is not dangerous but is something that should be suspected and conducted examination as a state probably by health personnel.

\section{Conclusion}

Based on the results of research conducted can be drawn conclusion as follows:

1. Predisposing factors that have relationship to health seeking behavior are health education and belief. The age variable, marital status, occupation, history of breast cancer and knowledge have no relation to health seeking behavior in breast cancer patients.

2 . The three variables in the supporting factors of income, ownership of access to health care and access to health services have nothing to do with health seeking behavior.

3. Based on the relationship between the overall variables obtained using logistic regression analysis, the variables most closely related to health service search behavior are health confidence variables.

\section{References}

Abu-Helalah, A.M., Alshraideh, H.A., AlHanaqtah, M., Da'na, M., Al-Omari, A., \& Mubaidin, R. (2016). Delay in presentation, diagnosis, and treatment for breast cancer patients in Jordan. Breast J, 22(2), 213-217. doi:10.1111/tbj.12541.

Anggraeni, R., Ngatimin, R., \& Arsin, A. (2012). Deteksi dini pada penderita kanker payudara stadium lanjut di RSUD Labuang Baji Makassar. (Early Detection of Advanced Stage Breast Cancer Patients at RSUD Labuang Baji Makassar.)

Arndt, V., Sturmer, T., Stegmaier, C., Ziegler, H., Dhom, G., \& Brenner, H. (2002). Patient delay and stage of diagnosis among breast cancer patients in Germany - A population based study. British Journal of Cancer, 86, 1034-1040. doi:10.1038/sj/bjc/6600209.

Brousselle, A., Breton, M., Benhadj, L., Tremblay, D., Provost, S., Roberge, D., ..., Tousignant, P. (2017). Explaining time elapsed prior to cancer diagnosis: patients' perspectives. BMC Health Serv Res, 17(1), 448. doi:10.1186/s12913-017-2390-1.

Dahlan, M.S.. (2012). Statistik untuk kedokteran dan kesehatan: Deskriptif, bivariat, dan multivariat, dilengkapi dengan menggunakan SPSS (Edisi 5). (Statistics for Medicine and Health: Descriptive, Bivariate, and Multivariate, Completed Using SPSS. 5th edition). Jakarta: Salemba Medika.

Glenz, K. et al. (2002). Health behaviour and health education: Theory, research, and practice (3rd Ed.). San Fransisco: Jossey Bass.

Hikmanti, A. dkk. (2007). Analisis faktorfaktor yang mempengaruhi keterlambatan pengobatan pada wanita penderita kanker payudara. (Analysis of Factors Affecting Delay in Treatment in Women with Breast 
Dini Fathania: Factors that Corelate with The Health Services Seeking on Breast Cancer Patients

Cancer). Purwokerto: STIKES Harapan Bangsa Purwokerto.

Kementerian Kesehatan RI. (2015). Pusat data dan informasi Kementerian Kesehaan $R I$. (Center for Data and Information of the Ministry of Health of the Republic of Indonesia). Jakarta : Kementerian Kesehatan RI.

Kusumawati and Miasari. (2014). The relationship between risk factor and early detection of breast cancer among fertile women. Kesmas, 8(1) September 2014, pp 101-108 ISSN : 1978-0575

Mbuka-Ongona, D., \& Tumbo, J.M. (2013). Knowledge about breast cancer and reasons for late presentation by cancer patients seen at Princess Marina Hospital, Gaborone, Botswana. African Journal of Primary Health Care \& Family Medicine, 5(1). doi:10.4102/ phcfm.v5il.465.

Melo, F.B.B., Marques, C.A.V., Rosa, A.D.S., Figueiredo, E.N., \& Gutierrez, M.G.R. (2017). Actions of nurses in early detection of breast cancer. Rev Bras Enferm, 70(6), 11191128. doi:10.1590/0034-7167-2016-0155.

Memon, Z.A., Shaikh, A.N., Rizwan, S., \& Sardar, M.B. (2013). Reasons for Patient's delay in diagnosis of breast carcinoma in Pakistan. Asian Pacific Journal of Cancer Prevention, 14(12), 7409-7414. doi:10.7314/ apjcp.2013.14.12.7409.

Mirfarhadi et al. (2017). Predictive factors for diagnosis and treatment delay in Iranian women with breast cancer. Nursing and Midwifery Studies In press 10.17795/nmsjournal27452. doi: 10.5812/ nmsjournal.27452

Moatter, T. et al. (2015). Cyclooxygenase-2 polymorphisms and breast cancer associated risk in Pakistan pattients, 97-101. http://doi. org/10.1007/s12253-014-9792-8.

Notoatmodjo, S. (2012). Promosi kesehatan dan perilaku kesehatan. (Health Promotion and Health Behavior). Jakarta : Rineka Cipta.

Nursalam. (2013). Metodologi penelitian ilmu keperawatan. (Nursing Research Methodology). Jakarta: Salemba Medika.

Pahria. (2017). Indonesian women diagnosed with breast cancer: A hermeneutic process. $\mathrm{PhD}$ thesis, Queensland University of Technology

Rahayuwati, L., \& Ibrahim, K. (2016). Health seeking behavior on breast cancer therapies: Patients versus providers views. Journal of Community \& Public Health Nursing, 2(3). doi:10.4172/2471-9846.1000129.

Rossalia, N.P.P., \& Wibawa, I.B.T. (2016). Faktor-faktor yang berhubungan dengan keterlambatan pengobatan pada penderita kanker payudara di rumah sakit umum pusat (RSUP) Sanglah Denpasar. (Factors related to treatment delays in breast cancer patients at the Central General Hospital (RSUP) Sanglah, Denpasar). E-Jurnal Medika, 5(12). ISSN: 2302-1395.

Unger-Saldana, K., Miranda, A., ZarcoEspinosa, G., Mainero-Ratchelous, F., Bargallo-Rocha, E., \& Miguel LazaroLeon, J. (2015). Health system delay and its effect on clinical stage of breast cancer: Multicenter study. Cancer, 121(13), 21982206. doi:10.1002/cncr.29331.

Wang, L. (2017). Early diagnosis of breast cancer. Sensors, 17, 1572; doi:10.3390. Diakses pada tanggal 24 Juli 2017.

World Health Organization. (2017). Cancer. retrieved from http://www.who.int/ mediacentre/factsheets/fs297/en/.

Yang Liu, M., Jian Zhang, MDa, Rong Huang, MDb,c, Wei-Liang Feng, MDd, YaNan Kong, MDe, Feng Xu, M., Lin Zhao, $\mathrm{MDg}$, Qing-Kun Song, MDb, Jing Li, MDb, Bao-Ning Zhang, MDh, Jin-Hu Fan, MDb, \& You-Lin Qiao, M., PhDb, Xiao-Ming Xie, MDe, Shan Zheng, MDi, Jian-Jun He, MDa, $\square$, Ke Wang, MD, PhD. (2017). Influence of occupation and education level on breast cancer stage at diagnosis, and treatment options in China. Medicine, 96(15). doi:10.1097/MD.0000000000006641. 